\title{
Cultural Relations: Javanese Elements in Macapat Metre Composed in Madura
}

\author{
Anasom $^{1}$, Nur Ahmad ${ }^{2}$ \\ 1,2 Universitas Islam Negeri W alisongo Semarang \\ e-mail: anasom@walisongo.ac.id
}

\begin{abstract}
ABSTRAK: Penelitian ini bertujuan untuk mendeskripsikan unsur-unsur sastra tradisional Jawa yang terdapat dalam teks macapat Madura. Dengan sumber utama naskah Sumenep, penelitian ini menggunakan analisis filologis terbadap teks tersebut. Dalam teori analisis intertekstual, artikel ini mengklaim menemukan unsur-unsur tradisi Jawa dalam teks Madura. Temuan ini penting untuk mendukung citra kompleks hubungan budaya kedua masyarakat yang diperkenalkan oleh beberapa sarjana. Dalam artikel ini, penelitian sebelumnya juga memberikan petunjuk tentang penyebaran luas bahasa Jawa dalam konteks Madura beberapa abad yang lalu.
\end{abstract}

Keyword: Javanese macapat, Madurese macapat, cultural relations, traditional literatures

\section{INTRODUCTION}

The success of Walisongo's preaching in the archipelago is believed to be based on their ways of cultural strategies. It is believed that they put Islamic values and practices into the thick pile of pre-Islamic culture. In this process, arts as the preaching medium found its best articulation. Some of the artistic means to disseminate Islam are gamelan, various ceremonies, wayang performances, and tembang macapat. At first, the macapat song was used as a medium to praise God in the surau before the canonical prayers established. The song is in Javanese language.

In addition to praise to God, the song conveys teachings, admonitions, as well as an invitation to advance morality of the people and to seek the essence of truth of religious rituals. Through the traditional Javanese music, every human heart is invited to deepen and understand the meaning of life.

Like the Javanese macapat, the Madura's song is also composed for the same goals. It contains beautiful verses, with content of teachings, admonitions, and invitations to the door of religious piety. This composition is easily understood by the readers and the listeners. So that the values of noble character, honesty, discipline, trust, and implicit and explicit religious values are more easily implanted in the heart. These values are expected to be able to produce a human of civilization and at the same time become a Muslim as a complete human being.

In the era of its popularity, Madurese macapat played a significant role. Macapat is not only a show, but also a time of disseminating ideas. In the form of "nogemi" (storytelling), the singer of the macapat passage interpret the content of the story book he or she read before. For this reason, the skill to sing macapat Madura has a prestige value that can be compared to the ability to recite the Koran in the Indonesian society today. 
However, historically Madurese macapat cannot be separated from Javanese macapat. Bouvier reveals that the Madurese macapat originated from Java. For the East Java region, the development of macapat can be traced to its development, Madurese writers took the initiative to compose macapat in Madurese language. Their essays also still adhere to Javanese macapat in terms of basic notation, types of macapat, provisions on the number of lines in the stanza and the final sound. ${ }^{1}$

One of the manuscripts originating from the island of Madura is belonged to K. H. Masduki, which is located in the Gapura sub-district, Sumenep Regency, East Java. The manuscript is written in Arabic script and a mixture of two languages, namely Javanese and Madurese in the form of prose. In addition, the manuscript contains a collection of macapat songs, in several metre including "senom", "kumambang", "artate", "pangkor", "kasmaran", "kinanthi", and "durma".

Bouvier further explains that the scarcity of literary creativity in the Madurese language in the Sumenep palace seems to be an explanation as to why the books that are scattered in the villages are written in Javanese, which seems to be a copy of the palace texts. Because "mamaca" is based on reading written texts, the renaissance of Madurese literature in Madura language, in the early 20th century, only occurred among Sumenep scholars and did not touch the villages at all. ${ }^{2}$

With this background, this research is a humble effort to make Bouvier's claim into detail. The way(s) in which the tradition of Madurese macapat is influenced by Javanese macapat.

\section{MACAPAT IN MADURESE TRADITION}

Literary work as a cultural product is closely related to the taste, creativity and will of the people. Through literary works, people reflect on themselves and their communities. In this case, the existence of literary works depends on the socio-cultural development of society. On the other hand, literature has an important role in recording the socio-culture of society.

Taum states that literary works (oral) are not just a means of entertainment, but can also act as a means of communication or cultural expression of the community. This means that with these (oral) literary works, the community transforms and develops knowledge about morals, customs, and other issues. ${ }^{3}$

Teeuw also reveals that the existence of oral literature in the past has quite an important meaning. It is inseparable from the existence of oral literature which continues to be created and lived by the community as a literary form, in addition to written literary forms. This means that oral literature for all cultures of Indonesian society is the main element in the creation and preservation of culture. Oral literature is the starting point for that culture to be understood and developed. ${ }^{4}$

Oral literature for traditional societies can be intended as a forum for wisdom that contains values of customs, conventions, value systems and various norms that apply in

\footnotetext{
${ }^{1}$ Helene Bouvier. 2002. Lèbur: Seni Musik Dan Pertunjukan Dalam Masyarakat Madura. Translated by Rahayu S. Hidayat and Jean Couteau. (Jakarta: Yayasan Obor Indonesia), 160

2 ibid

${ }^{3}$ Yoseph Yapi Taum. 2020. Sastra dan Politik Representasi Tragedi 1965 dalam Negara Orde Baru. (Sanata Dharma University Press), 1

${ }^{4}$ A Teeuw. 1984. Sastra dan Ilmu Sastra: Pengantar Teori Sastra. (Jakarta: Pustaka Jaya), 230.
} 
that society. ${ }^{5}$ With oral literature, based on its performance, content and existence in society, the views and patterns of life of a society can be known. Fox asserts that oral tradition is a description of society which is expressed and projected over a certain period of time. ${ }^{6}$ Tuloli adds that oral literature can be used to express the state of a society in the past which is almost forgotten. ${ }^{7}$

In the era of its popularity, Madura macapat art played a significant role. Macapat art is not just a show, but for some Madurese people it is used for nogemi (fortune-telling), namely by interpreting the content / storyline by pointing to the previous story book page. The ability to read Madura macapat songs also has a prestige value that can be compared to the ability to recite the Koran.

Historically, Madura macapat cannot be separated from Javanese macapat. Bouvier $(2002,160)$ reveals that the Madura macapat originated from Java. For the East Java region, the development of macapat can be traced to pre-Islamic times, namely before the 15th century. ${ }^{8}$

Madurese literature is full of messages, impressions, criticisms and teachings. In the past, Madurese oral and written literature was in great demand by the public, both from the common people and among the elite or aristocrats. Madurese literature is preferred because it is with this that the Madurese people can express themselves, convey moral messages, heart turmoil, and religious teachings. Madurese are known to have a tough character in living their lives, always go forward to challenge harsh conditions, it turns out that in their daily lives they still have time to create and chant literature. The geographical conditions of Madura, which are hot and confined by fierce ocean waves, have a strong influence on literary forms and moral messages that exist in the literature of the Madurese people. Mostly, Madurese literary works are filled with motivational, strict teaching messages.

The Mamaca oral tradition known in Madura seems to have had a connection with the macapat tradition that lived and developed on the island of Java (especially Central Java) since the Mataram era. ${ }^{9}$ The existence of the Mamaca oral tradition is closely related to the social life of the people who support it. This tradition was born as a means of fulfilling the needs of the community in which the tradition grows and develops. The Madurese community is known for having a very strong religious tradition (Islam). ${ }^{10}$ The presence of the Mamaca oral tradition emphasizes the characteristics of the Madurese community because the Mamaca offerings are sourced from didactic texts and morality influenced by Islamic culture.

Mamaca in the sense of Madurese is "reading". Understanding "mamaca" in terms is an activity to read the text in the form of a story in a way that is sung, then interpreted. The story has Malay Arabic text which uses Javanese courts, there is also mixed Javanese (Javanese and Madurese). Therefore, when read in an event, it must be "e" "tegghes" so that people who listen can understand the story being developed.

\footnotetext{
${ }^{5}$ Ibid, 444

${ }^{6}$ James J Fox. 1986. Bahasa, Sastra Dan Sejarah. Kumpulan Karangan Mengenai Masyarakat Pulau Roti. (Jakarta: Penerbit Djambatan), 2-4

${ }^{7}$ Nani Tuloli. 1990. Tanggomo: Salah Satu Ragam Sastra Lisan Gorontalo. (Intermasa), 3

${ }^{8}$ Helene Bouvier, of.cit

${ }^{9}$ F. A. Soetjipto Tjiptoatmodjo. 1983. "Kota-Kota Pantai Di Sekitar Selat Madura, Abad 17 Sampai Medio Abad 19.” (Disertasi, Yogyakarta: Universitas Gadjah Mada), 18-21

${ }^{10}$ Helene Bouvier, of.cit, 119
} 
The term mamaca in Madura can be compared to macapat in Java. In the Madurese tradition, the mamaca tradition is carried out in various ceremonies, and the mamaca song is usually read by men which at least consists of: (1) A story developed by pamaos, then translated by tokang tegghes. In this song and mantra, pamaos and tokang tegghes shout, so that both sound and content overlap tremendously. (2) Pamaos and tokang tegghes present the story in recitation. Tokang Tembhâng sings with extraordinary freedom. Tokang tegghes also show their ability to make words so expressive. Both try to bring words, dialogue, and description to life in the form of poetry. (3) The mamaca (macapat) program is held at arisan, rokat bhuju ', rokat bengko, circumcision ceremony, marriage, mamapar, nazar, Islamic holidays and necromancer events. (4) The scarcity of literary creativity in the Madurese language is one reason for the survival of Javanese language books in villages in Madura. The Madurese literary renaissance took place among intellectuals only. ${ }^{11}$

In the area of Sumenep Regency, a performing art called Mamaca has developed. In performing activities, Mamaca art is performed by men. Conceptually Mamaca (Madurese language) means reading a story that comes from a certain text. This manuscript is also called Kitab or more commonly heard as Layang. Reading activities are carried out by taking turns one by one and sometimes together. A person who acts as a Mamaca singer is called pamaos, which means reader. The rhythm of the reading song follows various slendro-tuned development patterns that frame the sentences read from the Kitab or Layang. These development patterns are identical to the macapat tradition as in Java. ${ }^{12}$

The manuscript which is called Kitab or Layang as a reading source is written in Pégon Arabic and in New Javanese. Kitab or Layang contains various stories influenced by Islamic culture. Therefore, one of the Mamaca actors acted as a translator or called panegghes by using the Madurese language. Panegghes conveys the meaning of sentences read by pamaos in New Javanese into Madurese. The Madurese translation is delivered alternately with pamaos when sentence by sentence or verse by verse is finished. The presentation of Mamaca is sometimes accompanied by the sound of a flute blowing.

Damono sees that in its development the relationship between oral and media is quite unique. Poets who are familiar with and are good at writing their works are influenced by oral factors in the reading of their works. This oral factor can be seen in the creativity of the poet when speaking his poetry. In several musical performances of Sosiawan Leak's poetry, text is limited to being a tool for poets to build story constructs or poetry lines. ${ }^{13}$

The art of macapat in Madura is an oral tradition that is starting to be neglected. In the 1980s, the Research Team of the Faculty of Letters, State University of Jember noted that public interest in the art of Madura macapat was diminishing. This is caused by two things. First, the difficulty of the literary language (macapat) of Madura. Macapat art, which requires understanding and the ability to sing songs with difficult notations, pațèt and changkok, causes the public to be less interested. Second, the emergence of modern art.

${ }^{11}$ Helene Bouvier, of.cit, 158

12 Kusmayati. 2000. Arak-Arakan: Seni Pertunjukkan Dalam Upacara Di Madura. (Yogyakarta: Tarawang).

13 Sapardi Djoko Damono. 1989. Novel Jawa Tahun 1950-an: Telaah Fungsi, Isi, Dan Struktur. Jakarta: Pusat Pembinaan dan Pengembangan Bahasa), 4 
Modern arts that are more practical and easy to understand, such as dangdut music, bands, films, dance, painting, drama and others, have shifted the position of Madura macapat art. Apart from being praised, it also contains teachings, suggestions and invitations to love science, teachings to jointly fix the corruption of morals and character, seek the essence of truth and shape human personality and culture. Through this song, every human being has his heart tapped to better understand and deepen the meaning of life. The poetry of tembang macapat is a manifestation of the relationship between humans and nature, as well as human dependence on the Lord of the Universe. ${ }^{14}$

Both the text and the context are considered to have similarities between the Madura macapat tembang and the Javanese macapat tembang. According to Bouvier all researchers agree that the Madura art of mamaca originated from Java. According to Pigeaud, the origin must be sought, for East Java in pre-Islamic times, namely before the 15th century. According to Munardi, et al, in Madura, reading books are used in Madurese and Javanese languages, and in Javanese or Arabic characters. Bouvier witnessed its use written in Javanese Kawi, and in Arabic script. Imron mentioned that the tembhang corpus was wider than what I had witnessed. Some of the tembhang, he said, were written in Madurese and originated in the early 20th century. However, he also emphasized that the most popular tembhang was borrowed from Javanese literature. ${ }^{15}$

Bouvier further explains that the scarcity of literary creativity in the Madurese language in the Sumenep palace seems to be an explanation as to why the books that are scattered in the villages are written in Javanese, which seems to be a copy of the palace texts. Because mamaca is based on reading written texts, the renaissance of Madurese literature in Madura language, in the early 20th century, only occurred among Sumenep scholars and did not touch the villages at all. ${ }^{16}$

During its development, Madurese writers took the initiative to compose macapat in Madurese language. Their essays are still guided by Javanese macapat in terms of basic notation, types of macapat, provisions for the number of lines in stanzas and the final sound.

The Maqamat manuscript which is the source of this study can be identified as follows: the text is written in Arabic script with Javanese society and language (pegon letter), the letter length is $1 \mathrm{~cm}$. The word "makamat" is listed on the title page in Latin letters. Manuscript size; $20.5 \mathrm{~cm}$ long and $16 \mathrm{~cm}$ wide. Text size; $14 \mathrm{~cm}$ long and $11.5 \mathrm{~cm}$ wide. The manuscript is written on paper made of bark. The text is written in black ink and several sentences using red ink as emphasis. Pages totaling 168, each page generally consists of 14 lines, on the first page there are 13 lines. In the text, there are no names of authors or copyists of the manuscript. In general the condition of the manuscript is still good, the writing can be read, only the binding has begun to break down. Manuscript covered in thick black paper, on the front page there is a flower motivation on the edge of the paper.

The manuscript contains four texts, namely, (1) the text contains the problem of fiqh consisting of three chapters, namely the wudlu, thaharoh and prayer chapters, there is

14 Team Penelitian Fakultas Sastra Universitas Negeri Jember. 1980. Seni Macapat Madura. (Jember: Proyek Penelitian Madura dalam Rangka Kerjasama Indonesia-Belanda untuk Pengembangan Studi Tentang Indonesia), 62

${ }^{15}$ Helene Bouvier, of.cit, 160

16 ibid 
no author or copyist name and the time of writing, (2) the text begins with basmallah and is in the form of a synom song containing ubudiyah problems such as wudlu and hadats. At the beginning, it is stated that this book is a message from the wali of Shaykh Muhammad Ibnu Abdul Karim Saman, quoted from the will of Shaykh Tajudin, his son, Shaykh Zakaria, the guardian of Sufi science, (3) the text in the form of tembang kasmaran contains the problem of Sufism. Written by a kyai Sumber named Abu Mufti al-Hajj Muhammad Maghfur and finished on the 3rd day of the 6th month of 1312 Hijriah, (4) the text in the form of a masumambang tembang contains tawhid, finished written at dhuha time, the 3rd day of the 6th of the year ba. There is no known name of the author or copyist of the manuscript. In this fourth section there is a blank page.

\section{CULTURAL RELATIONS: INTERTEXTUALITY BETWEEN JAVANESE AND MADURESE MACAPAT}

Macapat Madura comes from Javanese macapat. Both the text and the context are considered to have similarities between the Madura macapat tembang and Javanese macapat tembang. According to Bouvier all researchers agree that the art of Madurese mamaca originated from Java. According to Pigeaud, the origin must be sought, for East Java in pre-Islamic times. Because it originated from one tree, the Macapat Madura flower had many similarities and similarities with the Javanese Macapat song. Both are bound by a tembang rule, namely the number of gatra (padde) of each song is different, following the rules of the same song teacher and wilangan teacher. ${ }^{17}$

The difference lies in the lyrics sung, in the Javanese Macapat tembang the verse follows the rules of musical notes or numbers, while in Madura it prefers cengkok or song. Bouvier witnessed that its use was written in Kawi Javanese, and in Arabic script. Imron said that the Tembhang corpus is more According to him, some of the tembhang is broader than what I saw, written in Madurese and date back to the early 20th century. However, he also emphasized that the most popular tembhang was borrowed from Javanese literature.

The art of reading tembang originating from Java has also grown to Madura Island. However, people are now starting to be marginalized and abandoned, especially in Madura. Macapat has deep meaning. Hearing it can be soothing to the heart. Especially if you can know the meaning, it will be very meaningful in life.

The Macopat Madura song is categorized into three types, namely the king song, the middle song and the Macapat song or the kene song. Tembang Macapat or tembang kene 'there are 11 songs, namely; (1) Salanget (Kinanti), (2) Pucung, (3) Mejil (Medjil), (4) Maskumambang, (5) Durma, (6) Kasmaran (Asmaradana), (7) Pangkor, (8) Senom (Sinom ), (9) Artate '(Dandanggula), (10) Megattro (Megatruh), (11) Gambuh.

The form of the tembang is inseparable from the aesthetic structure of the poetry which emphasizes more on rhythm. While the content of the tembang contains extraaesthetic elements that show the nobility of the author. The macapat song in the maqamat script created through macapatan has vertical prophetic value, as well as horizontal social value. Describes hablumminallah and hablumminannas, including the socio-cultural background of the people.

17 ibid 
In addition to containing praise, it also contains teachings, suggestions and invitations to love science, teachings to jointly fix moral and moral defects, seek the essence of truth and form a human personality and culture. Through this song every human being can tap his heart to better understand and deepens the meaning of life. Macapat song poetry is a manifestation of the relationship between humans and nature, as well as human dependence on the Lord of the Universe.

Bouvier further explains that the scarcity of literary creativity in the Madurese language in the Sumenep palace seems to be an explanation as to why the books that are scattered in the villages are written in Javanese, which seems to be a copy of the palace texts. Because mamaca is based on reading written texts, the renaissance of Madurese literature in Madura language, in the early 20th century, only occurred among Sumenep scholars and did not touch the villages at all. ${ }^{18}$

In Gresik, the birth of the macapatan tradition cannot be separated from the role of sanga guardians and masters of Sufism who carry out the spread of Islam on the north coast. The never-ending role of wali sanga with a prophetic spirit to spread Islamic teachings to Sumenep has given birth to macapatan songs as a means of convincing the public to implement the essential teachings of Islam.

macapatan who were born in Sumenep and Gresik have the same characteristics in terms of text characteristics. These characteristics, such as the use of (1) gatra, (2) song teachers, (3) wilangan teachers, (4) tembang character, and (5) pedotan. However, in the reading of the tembang, the Sumenep macapatandi tradition uses the tokang tegghes as explained in the beginning, while in Gresik it does not.

These findings indicate that the Madurese macapat song does not yet have an independent character, and is still subordinate to the Javanese oral tradition. This description is then generalized as a general cultural description, that Madurese culture is an inseparable part of Javanese culture. through this research.

\section{ELEMENTS OF THE MADURESE MACAPAT}

The Madurese people argue against the perception of outsiders (Javanese) who think that the Madurese macapat / mamaca is the embryo of Javanese culture. Even though there is more or less influence from Javanese culture that comes from the kraton, this does not mean that Madura does not have its own cultural roots distinctive in itself. And the perception that mamaca in Madura is an imitation of Javanese culture is more likely to be related to the problem of delayed information transfer.

The dynamics of "mamaca" culture in Madura are a manifestation of people's defensiveness towards the arts passed down from their ancestors. During its development, it could not be separated from the transition of Hindu teachings where in the subsequent developments Hindu philosophy became verses containing Islamic philosophical values as core values. This is related to the role of preachers in the past who made art as a medium for preaching. ${ }^{19}$

Previous preachers created creative and innovative songs containing religious doctrine, praises to God, encouragement, and an invitation to love science. Calling out

\footnotetext{
18 ibid

19 Mien A Rifai. 2007. Manusia Madura: Pembawaan, Perilaku, Etos Kerja, Penampilan, Dan Pandangan Hidupnya Seperti Dicitrakan Peribahasanya. (Pilar Media).
} 
religious messages: morality, seeking and contemplating the essence of truth and the formation of a man with a personality and culture. Through the mamaca song, every human being has a heart tap to understand and deepen the meaning of life.

In its journey, as a form of cultural preservation effort, in the villages the name arisan-arisan is held. Or the community is more familiar with the term kompolan mamaca. In this collection, besides reading macapat, money is also withdrawn, the nominal value of which is actually not too large, because for the substance of them (the community) is the macapat, not the arisan. Asrisan is only one of the media to be able to preserve the macapat culture.

In addition to a collection of mamaca, macapat is also usually recited in certain events in the village, such as when in a Rokat, which is a bath that is done to a pregnant married couple, and at other events. ${ }^{20}$

For some rural communities, the culture of macapat is a very important culture. Even in the past, there was a village where in that village macapat was one of the conditions for people to get a fiancee. Even though there was no written agreement, it automatically became customary law in the village. a village. So learning macapat is also very important. Usually in the past, a child at the age of elementary school had started to learn macapat to certain people who were experts. After learning to read the Al-Qur'an or "nagaji" in Langgar, they usually go straight to study macapat. That is the existence of the Madurese culture called macapat.

However, along the way, this culture is not different from that of other Madurese cultures. Its existence in the midst of community life has begun to go unnoticed. So the name macapat is also almost "extinct". There are no longer many people who care and try to preserve it. Like in the village before, although not in writing it has become a prerequisite for getting engaged, now it is not again. Even tragically, now there are many Madurese who do not know this culture at all.

That is the sad reality about our cultural journey. The Madurese culture which has become an identity, or identity as the Madurese community has begun to be abandoned. The society that should try to preserve it sometimes is even more a priori towards such conditions. If that's the case, then Madura's future will definitely be bleak. If now what is starting to be lost is its culture, then no doubt in the following years just its Madura will also disappear from the vortex of the times. This is the biggest challenge for the Madurese people, namely caring for and preserving the cultures they have.

The Makamat manuscript is evidence of the existence of a relationship between Madurese culture and Javanese culture. The macapat song contained in the makamat manuscript. The maqamat script owned by K. H. Masduki is a teaching on Sufism. In the makamat script it consists of 7 types of macapat songs that are in it. Of the seven songs, there are 31 Pupuh.

1.Sinom

The sinom song contained in the makamat script is an attempt by the author as a da'wah interpreter to explain the Sufism teachings of Thoriqoh Assatariyah to the Madurese community. With the distinctive feature of the synom song that describes the human

${ }^{20}$ D. Zawawi Imron. 1989. Sastra Madura: Yang Hilang Belum Berganti Dalam Agama, Kebudayaan, Dan Ekonomi, Studi-Studi Interdisipliner Tentang Masyarakat Madura. (Edited by Huub de Jonge. Jakarta: Rajawali) 
relationship with Allah Hablumminallah and the human relationship with the strong fellow Hablumminannas. The author conveys the teachings.

Sinom, which means young leaves (pupus) of tamarind tree or fine hair on a woman's forehead, which means that joyful preaching will permeate the sense of Religion, which is an ornament for human life and makes humans full of hope (optimistic) and look young, because it is clean physically and mentally. Sinom by Sunan Giri. In the maqamat manuscript there are 6 stanzas and 108 verses of the synom song which teach about Thoriqoh Assatariyah.

2.Dandanggula

The dandanggula (artate) song has a pleasant character, its carrier is light and fun. Handhanggula which comes from dhandhang and sugar means hope for the sweet. Da'wah that is given in a delicious and fun way will bring hope to happiness. Dhandhanggula created by Sunan Kalijaga. In the maqamat manuscript there are 7 stanzas and 133 stanzas and tembang verses which teach about Thoriqoh Assatariyah.

3. Pangkur

Pangkur, which comes from ny deviating + mungkur, means that da'wah should never deviate and leave the contents of the Qur'an and Hadith, but distract and leave evil. Pangkur was created by Sunan Muria who was very firm in holding and implementing Islamic teachings according to the Qur'an and Hadith. This song implies one other side about the values of extraordinary happiness in humans. This happiness is achieved because of the success of carrying out His commands. That is an order to restrain lust, cleanse the heart, soul and mind and act honestly. The obligation to carry out His commands. In the maqamat manuscript there are 4 stanzas and 85 verses of pangkur tembang which teach about Syathariyah order.

4.Kasmaran

Kasmaran or asmarandana (Javanese) means like, Kasengsem (falling in love). This song is usually used to describe feelings of love or sadness. Besides that, it also gives a picture of feeling happy, happy, there are no difficult thoughts and always being in a happy state. Asmaradana comes from the word romance + dana means love + giving $=$ happy to give. Successful da'wah will be able to make people who like to give or like to issue donations, charity, charity, enlightenment, like helping fellow humans, because of Allah, sincere, without feeling arrogant. Asmaradana composed by Sunan Giri. The Kasmaran song in the makamat script has 4 stanzas and 85 stanzas.

5.Durma

Besides symbolizing human passions, this song implies a very close relationship between humans as social beings. In carrying out their lives, humans always have a dependence on other humans. With this dependence, each individual is required to be responsible for himself or others. Especially responsibility in carrying out duties. In the sense that the values of professionalism are really upheld by the Durma which teaches about Syathariyah order.

6.Kinanti

The period of identity formation from walking the path to ideals. Kinanthi comes from the word kanthi or demands which means that we need demands or the right path so that ideals can be realized. In the maqamat script there are 6 stanzas and 276 verses of the Selanget tembang. 
7.Maskumambang

Tembang Maskumambang implies a very harmonious, balanced and harmonious relationship between humans and all living things. With their intellect, humans are invited to read, listen to pay attention and think about and take advantage of the existence of other living things. This is in accordance with the human capacity as a mandate bearer. in the maqamat manuscript there are 3 stanzas and 48 stanzas of the maskumambang song which teaches about Syathariyah order.

\section{REFERENSI}

Bouvier, Helene. 2002. Lèbur: Seni Musik Dan Pertunjukan Dalam Masyarakat Madura. T ranslated by Rahayu S. Hidayat and Jean Couteau. Jakarta: Yayasan Obor Indonesia.

Damono, Sapardi Djoko. 1989. Novel Jawa Tahun 1950-an: Telaah Fungsi, Isi, Dan Struktur. Jakarta: Pusat Pembinaan dan Pengembangan Bahasa.

Fox, James J. 1986. Bahasa, Sastra Dan Sejarah. Kumpulan Karangan Mengenai Masyarakat Pulau Roti. Jakarta: Penerbit Djambatan.

Imron, D. Zawawi. 1989. Sastra Madura: Yang Hilang Belum Berganti Dalam Agama, Kebudayaan, Dan Ekonomi, Studi-Studi Interdisipliner Tentang Masyarakat Madura. Edited by Huub de Jonge. Jakarta: Rajawali.

Kusmayati, A.M. 2000. Arak-Arakan: Seni Pertunjukkan Dalam Upacara Di Madura. Yogyakarta: Tarawang.

Rifai, Mien A. 2007. Manusia Madura: Pembawaan, Perilaku, Etos Kerja, Penampilan, Dan Pandangan Hidupnya Seperti Dicitrakan Peribahasanya. Pilar Media.

Taum, Yoseph Yapi. 2020. Sastra dan Politik Representasi Tragedi 1965 dalam Negara Orde Baru. Sanata Dharma University Press.

Team Penelitian Fakultas Sastra Universitas Negeri Jember. 1980. Seni Macapat Madura. Jember: Proyek Penelitian Madura dalam Rangka Kerjasama Indonesia-Belanda untuk Pengembangan Studi Tentang Indonesia.

Teeuw, A. 1984. Sastra dan Ilmu Sastra: Pengantar Teori Sastra. Jakarta: Pustaka Jaya.

Tjiptoatmodjo, F. A. Soetjipto. 1983. "Kota-Kota Pantai Di Sekitar Selat Madura, Abad 17 Sampai Medio Abad 19.” Disertasi, Yogyakarta: Universitas Gadjah Mada.

Tuloli, Nani. 1990. Tanggomo: Salah Satu Ragam Sastra Lisan Gorontalo. Intermasa. 